\title{
Personal Exposure of Traffic Policeman to Particulate Matter in Jakarta: Distribution of Size, Chemical Composition, and Work Time
}

\author{
Doni Hikmat Ramdhan ${ }^{*}$, Eka Fitriani Ahmad1, Fitri Kurniasari³ ${ }^{3}$ Zuly Prima Rizky1, \\ Hardy Atmajaya ${ }^{1}$, Muhayatun Santoso ${ }^{2}$
}

\begin{abstract}
1 Faculty of Public Health, Universitas Indonesia, Indonesia, ${ }^{2}$ Center of Nuclear Technology for Materials and Radiometry, BATAN Bandung, Indonesia, ${ }^{3}$ Department of Occupational and Environmental Health, Graduate School of Medicine, Nagoya University, Japan
\end{abstract}

\begin{abstract}
Particulate matter (PM) is an air pollutant that has an impact on public health, especially in an urban area. The objective of this study was to analyze the personal concentration of $\mathrm{PM}_{2.5}$ and its composition among police working in the roadside area in Jakarta. PM measurement has done to the policeman that controlled traffic on four near highway locations in Jakarta. Sioutas impactor, Leland Legacy personal pump, and quartz fiber filter were chosen to measure the fine particles. Each PM was measured for 8-hour period. PM concentration was analyzed by the gravimetric method while tracing element and black carbon in $\mathrm{PM}_{0.25}$ by energy dispersive X-ray fluorescence (EDXRF) and EEL Smoke Stain Reflectometer. As a result, personal PM ${ }_{2.5}$ concentration in Jakarta during weekdays and weekends measurement are $93.43 \pm 10.84 \mu \mathrm{g} / \mathrm{m}^{3}$, and $75.68 \pm 12.01 \mu \mathrm{g} / \mathrm{m}^{3}$. S, K, Fe, Ca, Zn, and Pb are major elements found in all locations. The black carbon concentration during weekdays in all location was $11.46 \pm 6.97 \mu \mathrm{g} / \mathrm{m}^{3}$. A high concentration of fine particles, a traffic-related trace element in $\mathrm{PM}_{0.25}$, and black carbon are showed that traffic-related source is the major contributor to a high level of fine particulate matter at near highway locations in Jakarta. The weekday's concentration of $\mathrm{PM}_{2.5}$ and $\mathrm{PM}_{0.25}$ among Jakarta Policemen was higher than in the weekend concentration. A particle with size of less than $0.25 \mu \mathrm{m}$ dominated the fine particles concentration. Further researcher is expected to see the difference in the effects of traffic-related particulate matter exposure between traffic policeman and police who work at office.
\end{abstract}

Keywords: Black carbon, $\mathrm{PM}_{2.5}$, particulate matter composition, traffic-related particulate matter

\section{Introduction}

Air pollution is a major environmental health problem for both developed and developing countries that may affect human health. WHO reported that there was a steady increase in mortality rate that causes by air pollution from 2008 to $2014 .{ }^{1}$ Ambiance air pollution was assumed to hold responsibility for 1.3 million deaths in 2008, 3.7 million deaths in 2012, and 7 million deaths in 2014. ${ }^{1,2}$

Air pollution is the presence of one or more substances in the air that exceed the normal concentration and has the potential to affect human health. By their nature; air pollution source can be classified as natural and anthropogenic sources. The main sources in most areas are vehicle engine combustion, power plant emission, industrial and agriculture activities, cooking

How to Cite: Ramdhan DH, Ahmad EF, Kurniasari F, Rizky ZP, Atmajaya H, Santoso M. Personal exposure of traffic policeman to particulate matter in Jakarta: distribution of size, chemical composition, and work time. Kesmas: National Public Health Journal. 2019; 14 (2): 70-75. (doi:10.21109/kesmas.v14i2.3165) activity, re-emission from terrestrial and water surface, chemical production, distribution, and usage. ${ }^{3}$ Daily, weekly and seasonal changes of air pollution condition in an area are affected by source activity and meteorological factor.

Jakarta, the capital city of Indonesia, also has an air pollution problem. In the transportation sector, in 2014 , Jakarta has about 17 million registered motor vehicles. ${ }^{4}$ The fact above leads the road transportation section, along with the industrial section and the domestic waste incineration as a major source of particulate matter (PM) pollutant. ${ }^{5}$ Aside from increasing concentration of PM in air ambient, vehicle emission also a major contributor for the increasing concentration of nitrogen oxide (NOx) and other carbon emissions, such as carbon monoxide $(\mathrm{CO})$, black carbon $(\mathrm{BC})$, organic carbon $(\mathrm{OC})$ and

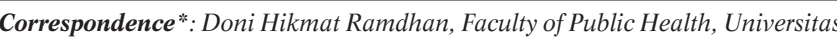
Indonesia, C Building 1st Floor Kampus Baru UI Depok 16424, Indonesia, Email: doni@ui.ac.id, Phone: +62 85697968639 Received : June $21^{\text {st }} 2019$

Revised : July 28th 2019

Accepted : September 30th 2019
} 
volatile organic compounds (VOCs). ${ }^{3} \mathrm{PM}$ is a liquid droplet and solid with a microscopic size that suspended in the air and can penetrate deeply into the human's lung and cause an adverse health effect. ${ }^{6} \mathrm{PM}$ is classified into 3 classes by size, ultrafine $(\leq 1 \mu \mathrm{m})$, fine $(1-2.5$ $\mu \mathrm{m})$, and coarse particles $(2.5-10 \mu \mathrm{m})$. Fine particulates (PM 2.5) is notorious for its health effect such as premature deaths in people with heart or lung disease, nonfatal heart attack, heart arrhythmias, aggravated asthma, decreased lung function, increased respiratory symptoms, such as irritation of the airways, coughing or difficultybreathing.

Health effect that caused by PM is affected by its concentration and exposure duration. The study by Committee on the Medical Effects of Air Pollution (COMEAP) shows that there is a correlation between daily exposure of PM with the acute effect of cardiovascular disease, based on the meta-analysis data, every concentration escalation of $10 \mu \mathrm{g} / \mathrm{m}^{3}$ will increase $1.4 \%$ rela tive risk of death by cardiovascular disease. ${ }^{7}$ The other review shows that every concentration escalation of PM in both short-term and long-term exposure has an association with the elevation of death from cardio vascular and lung disease, and from all-cause. ${ }^{8}$ While, the long-term exposure of PM has a correlation with the increase of blood markers from cardiovascular disease and elevate of histopathological markers from chronic subclinical lung inflammation and subclinical atherosclerosis.

Vehicle emission release abundance level of particulate matter, the previous study found that the fine particles concentration from vehicle source in motor vehicle testing center that exposes the mechanics extent to $149.01 \pm 60.33 \mu \mathrm{g} / \mathrm{m}^{3} .{ }^{9}$ On another study on PM effect from testing of male Fischer 344, it was found that particulate with nanometer size from diesel engine combustion process induces reproductive system disor-ders such elevation of testosterone level in low exposure and middle exposure group. ${ }^{10}$

The health problems that arise due to exposure to $\mathrm{PM}_{2.5}$ needs to be undertaken by preventing with a strategic and comprehensive strategy. One of the critical attempts made in disease prevention is to determine the concentration, composition, and size distribution by measure the personal exposure of $\mathrm{PM}_{2.5}$ at workers, who work in the roadside area. The objective of this study was to analyze the personal concentration of $\mathrm{PM}_{2.5}$ and composition among police who worked in the roadside area in Jakarta.

\section{Method}

This study was designed to show the size distribution and chemical composition of fine particles. PM collected for 8 hours from each worker on four roadside area in
Jakarta from March to May 2015. Six and four samples collected for weekday and weekend periods in every sample location. PM collection was done according to EPA IP 10 A adapted by SKC. Inc standard (SKC Inc., 2004). The PM concentration analyzed using gravimetric method while the element composition and black carbon were analyzed using Energy Diffraction X-ray Fluorescence (EDXRF) and EEL Smoke Stain Reflectometer respectively.

Fine particles were measured in four sample points in Jakarta. Harmoni, Senayan, Semanggi, and Pancoran were selected as a sample point due to the heavy traffic that always happened in those areas. Sample apparatus placed in the breath zone of the police officer for 8 hours during his shift. Fine particles were measured based on US EPA IP $10 \mathrm{~A}$ method that updated by SKC.Inc in 2004. Particulate matters were divided into five groups according to their size using Sioutas Impactor. Sioutas Impactor placed in the breathing zone area of the policeman. Ambient air sucked using Leland Legacy personal pump constantly on $9 \mathrm{~L} /$ minute during the measurement. Quarts fiber filter placed in every stage of the Sioutas impactor to filtering the PM.

The concentration of fine particles analyzed using the gravimetric method. Every filter is placed in a balance room for 24 hours prior to the initial and final weighing using microbalance. Qualitative and quantitative analysis of element composition were done using Energy Diffraction X-ray Fluorescence (EDXRF) in Center of Nuclear Technology for Materials and Radiometry, BATAN Bandung. EDXRF is stationary spectrometer and methodical analysis of energy-dispersive X-Ray Fluorescence. All of the sample element is excited by bombarding with high-energy X-rays, and an energy dispersive detector in combination with a multi-channel analyzer was used to simultaneously collect the fluorescence radiation emitted from the sample and to separate the different energies of the characteristic radiation from each of the different sample element. ${ }^{11}$

Black carbon concentration analysis was performed using EEL Smoke Stain Reflectometer. Diffusion of light produced by tungsten light will pass through the holes contained in the photocell is shaped like a bracelet, to project and determine sample point, then the light will be reflected back to the photocell. Reflectance obtained from the filter exposed (R in \%) will be compared with the reflectance of the empty filter $(\mathrm{R} 0=100 \%)$. Light reflected by the surface of the exposed filter will pass through several layers of particles on the surface two times, it causes attenuation upon reflection occurs two times. ${ }^{12}$

Continuous data will be displayed in the form of average with a standard deviation (SD) and data obtained from the exposed and unexposed groups are 
compared using a two-tailed t-test. This study has been reviewed by the Ethics Commission of Faculty of Public Health Universitas Indonesia (No. 71/2012).

\section{Results}

The t-test result in Table 1 shows that the concentration distribution for each PM size is higher on the weekdays than on the weekends. On the weekdays, the distribution of PM concentration is higher in the morning shift (06:00 a.m. - 02:00 p.m.) than in the afternoon shift (02:00 - 08:00 p.m). While, on the weekends, it is higher in the afternoon than in the morning shift, except at Harmoni. On the weekdays, the concentration of personal PM exposure on traffic police at Bundaran Senayan area is the highest concentration compared to other areas. However, on the weekends, the highest PM exposure concentration is at Pancoran.

Figure 1 displays the concentration of element composition from $\mathrm{PM}_{0.25}$ from four different locations in Jakarta. There is a similar pattern from elemental com-

Tabel 1. Size Distribution of Traffic Related Particulate Matter

\begin{tabular}{|c|c|c|c|c|}
\hline Location & Shift & Size $(\mu \mathrm{m})$ & Weekday & Weekend \\
\hline \multirow[t]{8}{*}{ Harmoni } & \multirow[t]{4}{*}{$\mathrm{AM}$} & $\mathrm{PM}_{2.5}$ & $89.25 \pm 16.95 \%, \#$ & $80.25 \pm 3.27$ \\
\hline & & $\mathrm{PM}_{1}$ & $65.59 \pm 5.83$ & $64.43 \pm 2.73$ \\
\hline & & $\mathrm{PM}_{0.5}$ & $49.90 \pm 2.36$ & $50.54 \pm 3.82$ \\
\hline & & $\mathrm{PM}_{0.25}$ & $47.48 \pm 5.70$ & $53.66 \pm 4.70$ \\
\hline & \multirow[t]{4}{*}{$\mathrm{PM}$} & $\mathrm{PM}_{2.5}$ & $83.33 \pm 14.04 *$ & $67.52 \pm 8.18$ \\
\hline & & $\mathrm{PM}_{1}^{2 . J}$ & $65.33 \pm 9.59 *$ & $58.26 \pm 8.18$ \\
\hline & & $\mathrm{PM}_{0.5}$ & $54.53 \pm 10.92$ & $50.54 \pm 7.09$ \\
\hline & & $\mathrm{PM}_{0.25}$ & $55.08 \pm 13.99$ & $55.08 \pm 2.69$ \\
\hline Bundaran & \multirow{4}{*}{$\mathrm{AM}$} & $\mathrm{PM}_{2.5}$ & $104.17 \pm 6.86^{*}, \#$ & $65.35 \pm 28.70$ \\
\hline \multirow[t]{7}{*}{ Senayan } & & $\mathrm{PM}_{1}^{2.5}$ & $76.90 \pm 3.96 \%$ & $48.38 \pm 19.97$ \\
\hline & & $\mathrm{PM}_{0.5}^{1}$ & $54.27 \pm 9.27 *$ & $38.97 \pm 16.91$ \\
\hline & & $\mathrm{PM}_{0.25}$ & $53.50 \pm 7.38^{*}, \#$ & $40.36 \pm 14.10$ \\
\hline & \multirow[t]{4}{*}{$\mathrm{PM}$} & $\mathrm{PM}_{2.5}$ & $88.22 \pm 6.35^{*}$ & $85.57 \pm 8.62$ \\
\hline & & $\mathrm{PM}_{1}^{2 . J}$ & $65.17 \pm 1.64^{*}$ & $63.27 \pm 4.36$ \\
\hline & & $\mathrm{PM}_{0.5}$ & $49.23 \pm 1.42$ & $49.38 \pm 2.18$ \\
\hline & & $\mathrm{PM}_{0.25}$ & $45.87 \pm 2.14$ & $47.48 \pm 0.00$ \\
\hline \multirow[t]{8}{*}{ Semanggi } & \multirow[t]{4}{*}{$\mathrm{AM}$} & $\mathrm{PM}_{2.5}$ & $93.88 \pm 5.25 *$ & $76.08 \pm 2.62$ \\
\hline & & $\mathrm{PM}_{1}^{2 . J}$ & $79.48 \pm 4.08^{*}, \#$ & $60.65 \pm 0.44$ \\
\hline & & $\mathrm{PM}_{0.5}$ & $71.50 \pm 4.45^{*}$ & $47.84 \pm 0.00$ \\
\hline & & $\mathrm{PM}_{0.25}$ & $51.70 \pm 5.40$ & $44.75 \pm 2.18$ \\
\hline & \multirow[t]{4}{*}{$\mathrm{PM}$} & $\mathrm{PM}_{2.5}$ & $85.57 \pm 2.74^{*}$ & $76.77 \pm 2.73$ \\
\hline & & $\mathrm{PM}_{1}^{2 . J}$ & $71.94 \pm 3.25^{*}$ & $62.50 \pm 1.09$ \\
\hline & & $\mathrm{PM}_{0.5}$ & $61.91 \pm 1.82 *$ & $51.70 \pm 1.09$ \\
\hline & & $\mathrm{PM}_{0.25}$ & $50.33 \pm 5.31 *$ & $44.37 \pm 0.55$ \\
\hline \multirow[t]{8}{*}{ Pancoran } & \multirow[t]{4}{*}{$\mathrm{AM}$} & $\mathrm{PM}_{2.5}$ & $86.42 \pm 3.36^{*}$ & $81.02 \pm 0.00$ \\
\hline & & $\mathrm{PM}_{1}^{2.5}$ & $66.10 \pm 5.25$ & $61.73 \pm 5.46$ \\
\hline & & $\mathrm{PM}_{0.5}$ & $54.27 \pm 1.94$ & $51.31 \pm 0.55$ \\
\hline & & $\mathrm{PM}_{0.25}$ & $40.12 \pm 3.54$ & $40.90 \pm 3.27$ \\
\hline & \multirow[t]{4}{*}{$\mathrm{PM}$} & $\mathrm{PM}_{2.5}$ & $89.76 \pm 12.47 *$ & $77.35 \pm 0.49$ \\
\hline & & $\mathrm{PM}_{1}^{2.5}$ & $52.21 \pm 8.25 *$ & $42.25 \pm 0.05$ \\
\hline & & $\mathrm{PM}_{0.5}^{1}$ & $40.12 \pm 5.56^{*}$ & $30.29 \pm 0.49$ \\
\hline & & $\mathrm{PM}_{0.25}$ & $32.92 \pm 4.96^{*}$ & $23.23 \pm 0.11$ \\
\hline \multirow[t]{8}{*}{ All } & \multirow[t]{4}{*}{$\mathrm{AM}$} & $\mathrm{PM}_{2.5}$ & $93.43 \pm 10.84^{*}$ & $75.68 \pm 12.01$ \\
\hline & & $\mathrm{PM}_{1}^{2.3}$ & $72.02 \pm 7.72$ & $58.80 \pm 9.62$ \\
\hline & & $\mathrm{PM}_{0.5}$ & $57.48 \pm 9.79$ & $47.16 \pm 7.85$ \\
\hline & & $\mathrm{PM}_{0.25}$ & $48.20 \pm 7.23$ & $44.92 \pm 7.61$ \\
\hline & \multirow[t]{4}{*}{ PM } & $\mathrm{PM}_{2.5}$ & $86.72 \pm 8.91$ & $76.80 \pm 7.71$ \\
\hline & & $\mathrm{PM}_{1}^{2 . J}$ & $63.66 \pm 9.34$ & $56.57 \pm 9.11$ \\
\hline & & $\mathrm{PM}_{0.5}$ & $51.45 \pm 9.85$ & $45.48 \pm 9.20$ \\
\hline & & $\mathrm{PM}_{0.25}$ & $46.05 \pm 10.97$ & $42.54 \pm 11.85$ \\
\hline
\end{tabular}

*p $<0.05$ compared with the Weekend group

$\# p<0.05$ compared with the PM group position distribution in all area, where sulphur (S), potassium $(\mathrm{K})$, iron $(\mathrm{Fe})$, carbon $(\mathrm{Ca})$, zinc $(\mathrm{Zn})$, and lead $(\mathrm{Pb})$ concentration were fairly high in all sampling area. If based on each location, the highest concentration of elements in Semanggi are S $\left(2.90 \mu \mathrm{g} / \mathrm{m}^{3}\right)$, Ca $(1.63$ $\left.\mu \mathrm{g} / \mathrm{m}^{3}\right)$, and $\mathrm{Zn}\left(1.4 \mu \mathrm{g} / \mathrm{m}^{3}\right)$. In Harmoni, there are Ca $\left(1.14 \mu \mathrm{g} / \mathrm{m}^{3}\right), \mathrm{Zn}\left(1.07 \mu \mathrm{g} / \mathrm{m}^{3}\right)$, and $\mathrm{S}\left(0.85 \mu \mathrm{g} / \mathrm{m}^{3}\right)$ as the highest element concentration. While in Pancoran the highest concentration are $\mathrm{Ca}\left(1.28 \mu \mathrm{g} / \mathrm{m}^{3}\right), \mathrm{S}(1,24$ $\left.\mu \mathrm{g} / \mathrm{m}^{3}\right)$, and $\mathrm{Zn}\left(1.14 \mu \mathrm{g} / \mathrm{m}^{3}\right)$. Then in Senayan are $\mathrm{Ca}$ $\left(1.89 \mu \mathrm{g} / \mathrm{m}^{3}\right), \mathrm{Zn}\left(0.89 \mu \mathrm{g} / \mathrm{m}^{3}\right)$, and $\mathrm{Fe}\left(0.65 \mu \mathrm{g} / \mathrm{m}^{3}\right)$ as the highest element concentration.

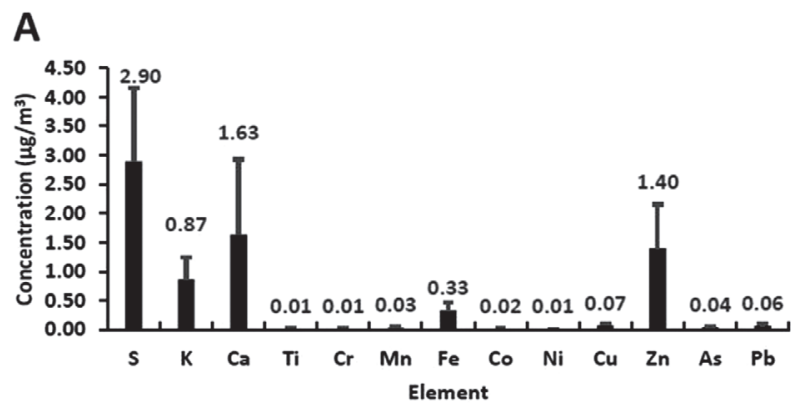

B
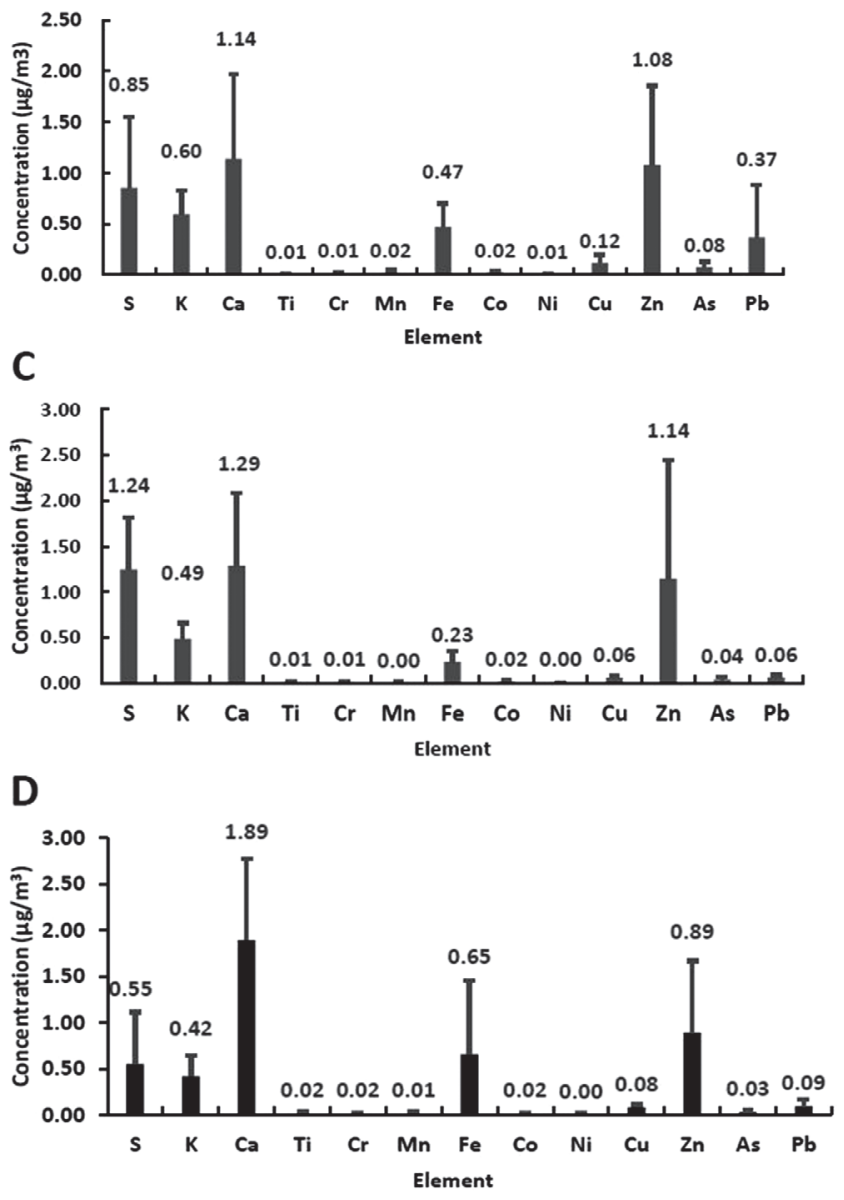

Figure 1. Chemical Composition of Traffic-Related Particulate Matter in Semanggi (A), Harmoni (B), Pancoran (C), and Senayan (D) 


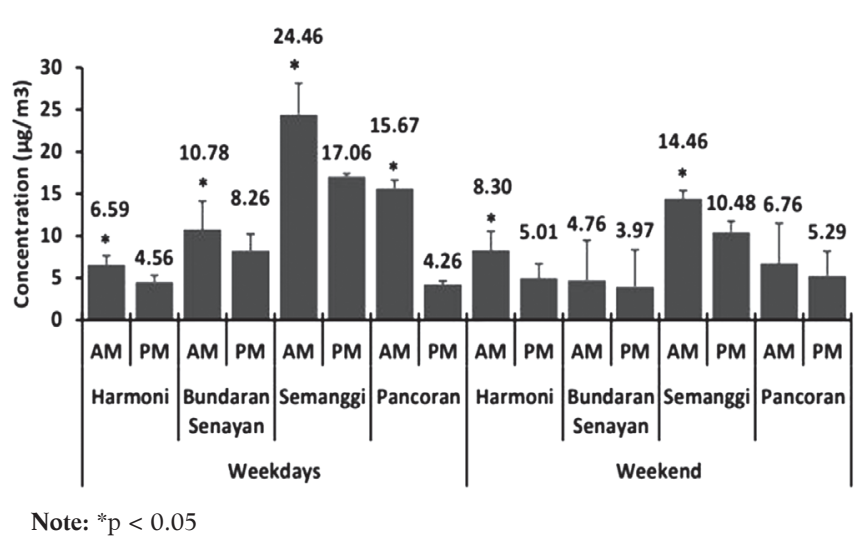

Figure 2. Black Carbon Concentration of Traffic-Related Particulate Matter

Figure 2 shows that the concentration of black carbon at each location is higher on the weekdays than on the weekends, except in the Semanggi. Based on work shifts, the concentration of black carbon is higher in the morning shift (06:00 a.m. - 02:00 p.m.) than in the afternoon shift (02:00 p.m. - 08:00 p.m.). Then, the location that has the highest black carbon concentration is Semanggi, and the lowest is Harmoni.

\section{Discussion}

The study showed that the personal concentration of $\mathrm{PM}_{2.5}$ and $\mathrm{PM}_{0.25}$ among Jakarta Policemen was higher on weekdays than on the weekend. A particle with a size of less than $0.25 \mu \mathrm{m}$ dominated the fine particles concentration. High levels of submicron/ultrafine particles indicated that vehicle emission coming from combustion and the high-temperature process was the major source of particulate matter in this study. $\mathrm{S}, \mathrm{K}, \mathrm{Fe}, \mathrm{Ca}, \mathrm{Zn}$, and $\mathrm{Pb}$ are an element with a high concentration in submicron particulate.

Reduced PM concentration during weekends due to the car-free day program that is held on Sundays. However, because it was only carried out on the NorthSouth route, which was around the Sudirman and Thamrin roads, PM concentrations in the East-West route, such as in the Pancoran area, has the highest concentration on weekends. Measurement point that located at the roadside of the highway is the main reason why the mean concentration of fine particles was fairly high. The other study stated there was a decrease in the mean concentration of fine particles particularly with size within $0.015-0.697 \mu \mathrm{m}$ along with the increasing distance between the highway and the sampling point; this indicates that particles within those sizes were linked to traffic activity. ${ }^{13}$ The high concentration of ultrafine particles $(<1 \mu \mathrm{m})$ is forming by combustion and high-temperature process. ${ }^{14}$ Furthermore, another study also found that vehicle emission is the source of the abundance of ultrafine particles, especially in an urban environment. ${ }^{15}$ This study showed that, on the weekdays, PM concentrations were higher in the morning shift. This might be due to the high number of vehicles on the highway. Based on previous study, vehicles on highways in the morning are higher and cause reemissions through circulation caused by passing vehicles. ${ }^{16}$

In the analysis, element composition in $\mathrm{PM}_{0.25}$, was obtained a fairly high sulphur (S) content, where the highest concentration reached $2,897.43 \mathrm{ng} / \mathrm{m}^{3}$ (Semanggi), while the lowest concentrations of reach $550.83 \mathrm{ng} / \mathrm{m}^{3}$ (Senayan). That result is in line with previous studies conducted around the highway in the Netherlands and Jakarta where the highest concentration of sulfur in fine particles reach to $1,426.60 \mathrm{ng} / \mathrm{m}^{3}$ and $1,177.02 \mathrm{ng} / \mathrm{m}^{3}$ respectively. ${ }^{17}$ The high concentration of $\mathrm{S}$ occurs due to sulphur usability as an impurity agent of fuel and lubricant additives. ${ }^{18}$ Cross \& Hunter, ${ }^{19}$ in another study stated that sulphur particles appear as a trace species of diesel engines fuels and as lubricants additives.

The emergence of potassium $(\mathrm{K})$ in the air is due to the number of vehicles using diesel engines with a lack of maintenance on the highway. A previous study conducted in 2008 - 2009 showed a considerable difference compared with the results obtained in the present study. Potassium levels found in that study are four times smaller if compared with the levels of potassium in the Semanggi area $\left(867.07 \mathrm{ng} / \mathrm{m}^{3}\right) .{ }^{17}$ In the study conducted in the Hsuehshan tunnel, Taiwan indicated that $\mathrm{K}$ has an association with the wear debris, resuspended dust, and emissions from gasoline-fueled vehicles. ${ }^{20}$ Potassium appearance also associated with diesel use for diesel engine and engine wear. ${ }^{19}$

$\mathrm{Fe}, \mathrm{Cu}$, and $\mathrm{Mn}$ are considered a fingerprint of the traffic-related dust. Based on measurements taken in Netherlands, the comparison of concentration levels of $\mathrm{Fe}, \mathrm{Cu}$ and $\mathrm{Mn}$ in $\mathrm{PM}_{2.5}$ between the highway and suburban locations in order are $1.9: 2.3: 1.4 .^{21}$ Moreover, $\mathrm{Fe}, \mathrm{Cu}$ and $\mathrm{Mn}$ concentration in Jakarta are $141.33 \mathrm{ng} / \mathrm{m}^{3}, 5.56 \mathrm{ng} / \mathrm{m}^{3}$, and $7.24 \mathrm{ng} / \mathrm{m}^{3}$ respectively. ${ }^{17}$ When compared to Senayan, Harmony, and Semanggi, which is the location that has the highest concentration of $\mathrm{Fe}, \mathrm{Cu}$, and $\mathrm{Mn}$, the levels obtained from previous studies are much lower. $\mathrm{Fe}, \mathrm{Cu}$, and $\mathrm{Mn}$ concentration in this study are six times, 20 times, and four times higher compared to the study conducted in Jakarta. ${ }^{17}$ Other studies related Fe states that the enrichment factor of iron (Fe) in the Hsuehshan tunnel entrance is at $5-11$, while the exit is at $12-21$, the difference of these enrichment factors indicate that the Fe contained in the tunnel mostly generated by anthropogenic emissions, not from road dust. ${ }^{20}$ Still from the 
same study, there is a correlation found among Fe with $\mathrm{Cu}, \mathrm{Ba}$, and $\mathrm{Sb}$ is all size particles (coarse, fine and ultrafine) as a proof that wears dust is the major contributor of Fe concentration in Hsuehshan tunnel.

Harmoni is a location with the highest $\mathrm{PM}_{0.25}$ and $\mathrm{Cu}$ concentration. $\mathrm{Cu}$ concentration in Harmoni surpass the $\mathrm{Cu}$ concentration from the previous study in Netherlands roadside, where $\mathrm{Cu}$ mean concentration in fine particles is $28.33 \mathrm{ng} / \mathrm{m}^{3} .22$ Other previous studies indicate that $\mathrm{Cu}$ was coming from wear-abrasive sources and wear debris. ${ }^{20-23} \mathrm{Cu}$ appearance is consistent in the roadside area because it is an additional material contained in lubricants, as well as forming during the braking process. ${ }^{23}$

Manganese (Mn) normal annual concentration both in a rural and urban area without manganese pollutant sources is between $0.01-0.07 \mu \mathrm{g} / \mathrm{m}^{3}$, while common $\mathrm{Mn}$ annual mean concentration in the area near the foundries and around Ferro- and silico-manganese industries may rise to $0.2-0.3 \mu \mathrm{g} / \mathrm{m}^{3}$ and $0.5 \mu \mathrm{g} / \mathrm{m}^{3}$ respectively. ${ }^{24}$ When compared to the standard before, Mn concentration in Jakarta is still considered safe. From the observation taken, there was no foundries nor Ferro- or silicomanganese industries around all the sample point. $\mathrm{Mn}$ in Jakarta air ambient may come from diesel engine exhaust. 20

Zinc $(\mathrm{Zn})$ is one element that has the highest concentration in all four test sites with mean concentration is $1,126.32 \mathrm{ng} / \mathrm{m}^{3}$. That concentration is considered fairly high compared to other studies. From the study conducted in Jakarta, $\mathrm{Zn}$ was detected up to 18 times lower than the levels of $\mathrm{Zn}$ Semanggi. ${ }^{17}$ Furthermore, on study conducted in Europe showed the average concentration of $\mathrm{Zn}$ in $\mathrm{PM}_{2.5}$ around the highway in Rotterdam and for eight highways in Netherlands amounted to 145.55 $\mathrm{ng} / \mathrm{m}^{3}$ and $25.57 \mathrm{ng} / \mathrm{m}^{3}$ respectively. ${ }^{21,22}$ Zinc itself is commonly used as additives or impurities from diesel fuel and lubricants, such as the zinc dialkyl dithiophosphate (ZDDP), which are additives used in a lubricant that is useful to improve the anti-wear properties and antioxidant abilities on fuel. ${ }^{25}$ Additives for lubricating oils such as calcium, zinc, and phosphorus generally cannot be detected on diesel fuel, based on that founding, $\mathrm{Zn}$ can be used as a fingerprint of organic aerosols generated from the lubricating oil contained in the diesel engines exhaust. 25

National Ambient Air Quality Standard (NAAQS) specify $0.15 \mu \mathrm{g} / \mathrm{m}^{3}$ as the limit concentration of lead $(\mathrm{Pb})$ in air ambient. For measurements taken at four locations in Jakarta, Harmoni had the highest concentration of lead at $0.37 \mu \mathrm{g} / \mathrm{m}^{3}$. Pb contained in Harmoni 4 - 6 fold higher compared to other locations, and nine times higher compared to previous studies. ${ }^{17} \mathrm{~Pb}$ itself has a strong correlation with $\mathrm{Zn}(\mathrm{r}>0.75)$ on fine-particle phase; it shows that $\mathrm{Pb}$ may be generated from diesel engines combustion process. ${ }^{20}$

The uppermost and the bottommost concentration of calcium $(\mathrm{Ca})$ in all sampling areas are located in Sena yan with $\left(1,892.52 \mathrm{ng} / \mathrm{m}^{3}\right)$ and Harmoni with $\left(1,140.62 \mathrm{ng} / \mathrm{m}^{3}\right)$. The obtained results from this study showed the differences compared to the previous study

in the Netherlands where $\mathrm{Ca}$ concentration in $\mathrm{PM}_{2.5}$ levels in eight locations highways was amounted to 38.04 $\mathrm{ng} / \mathrm{m}^{3} .^{21}$ Wear debris, road dust, and gasoline were the sources of Ca. ${ }^{20}$

Significant differences between this study and the previous study in Jakarta may occur as a result of several factors. Santoso measures the fine particles for 12 hours long, once in a week for one year period. ${ }^{17}$ Sampling method, material, and sampling location are quite different from this study that used personal sampler attached to the policeman who had to manage the traffic during the sampling period.

Black Carbon concentration in Semanggi is higher than the other studies. The US Environmental Protection Agency writes BC concentration from countries around the world in the report for the Congress of Black Carbon. ${ }^{26}$ China, as one of the countries with the highest level of BC, has a BC concentration of around $0.3-14.2$ $\mu \mathrm{g} / \mathrm{m}^{3}$ in 2006. Furthermore, BC measurements which were conducted in 12 locations in the UK in 2006 alone showed that the average annual concentration of Black Carbon in the UK amounted to $5.0-16.0 \mu \mathrm{g} / \mathrm{m}^{3}$. Both the UK and China have lower Black Carbon levels compared to the levels obtained in Semanggi. The measurement of Black Carbon that conducted in Pondok Indah Indonesia between 2008 - 2009 also showed that Black Carbon level in that location is still lower than Black Carbon level in Semanggi with a mean concentration of Black Carbon only around $8.17 \mu \mathrm{g} / \mathrm{m}^{3} .{ }^{17}$

Abundance pollutant from vehicle emission near the sampling location has a major influence of the high level of $\mathrm{BC}$ that trapped in the filter. Black carbon was formed from fossil fuels, biofuels, and biomass combustion process biomass. ${ }^{26}$ Contrast variation of Black Carbon concentration in an urban and rural area in China, where Black Carbon concentration in a rural area was about 0.3 - $5.3 \mu \mathrm{g} / \mathrm{m}^{3}$ while in urban area where up to $9.3-14.2$ $\mu \mathrm{g} / \mathrm{m}^{3}$ proved that traffic density take major rules in BC concentration in air ambient. ${ }^{26}$

\section{Conclusion}

In conclusion, the weekday's personal concentration of PM in Jakarta Policemen is higher than on the weekend. On weekdays, concentrations of PM are higher in the morning shift than in the afternoon shift. A particle with a size less than $0.25 \mu \mathrm{m}$ dominated the fine particles concentration. A high concentration of fine particles, a 
traffic-related trace element in $\mathrm{PM}_{0.25}$, and black carbon are showed that traffic-related source is the major contributor to a high level of fine particulate matter in Jakarta. Further researcher is expected to see the difference in the effects of traffic-related particulate matter exposure between traffic policeman and police who work at office.

\section{Acknowledgments}

The authors would like to acknowledge Sutrani Rachmawati for technical help.

\section{References}

1. World Health Organization. 7 million premature deaths annually linked to air pollution 2014 [cited 2019 10]. Available from: https://www.who.int/mediacentre/news/releases/2014/airpollution/en/.

2. World Health Organization. Burden of disease from household air pollution for 2012. Geneva; 2012.

3. Unger N, Bond TC, Wang IS, Koch DM, Menon S, Shindell DT, et al. Attribution of climate forcing to economic sectors. Proceedings of the National Academy of Sciences. 2010; 107(8): 3382-7.

4. Badan Pusat Statistik Provinsi DKI Jakarta. Statistik Transportasi DKI Jakarta 2015. Jakarta: Badan Pusat Statistik Provinsi DKI Jakarta; 2015.

5. Clean Air Asia. The Clean Air Management Profiles (CAMPs) Indonesia. 2010.

6. United States Environmental Protection Agency. Particulate Matter (PM) 2016. Available from: https://www.epa.gov/pm/.

7. Committee on the Medical Effects of Air Pollution. Long-term exposure to air pollution: effect on mortality; 2009.

8. Cao J, Yang C, Li J, Chen R, Chen Bu, Gu D, Kan H. Association between long-term exposure to outdoor air pollution and mortality in China: a cohort study. Journal of Hazardous Materials. 2011 Feb 28; 186(2-3): 1594-600.

9. Rizky ZP, Yolla PB, Ramdhan DH. Particulate matter 2.5 (PM2. 5) personal exposure evaluation on mechanics and administrative officers at the motor vehicle testing center at Pulo Gadung, DKI Jakarta. Reviews on Environmental Health. 2016; 31(1): 185-6.

10. Ramdhan DH, Ito Y, Yanagiba Y, Yamagishi N, Hayashi Y, Li C, et al. Nanoparticle-rich diesel exhaust may disrupt testosterone biosynthesis and metabolism via growth hormone. Toxicology Letters. 2009; 191(23): $103-8$

11. Wobrauschek P, Streli C, Lindgren ES. Energy Dispersive, X-Ray Fluorescence Analysis. Encyclopedia of analytical chemistry; 2010.

12. Taha G, Box GP, Cohen DD, Stelcer E. Black carbon measurement using laser integrating plate method. Aerosol Science and Technology.
2007; 41(3): 266-76.

13. Hitchins J, Morawska L, Wolff R, Gilbert D. Concentrations of submicrometre particles from vehicle emissions near a major road. Atmospheric Environment. 2000; 34(1): 51-9.

14. Lippmann M. Environmental toxicants: human exposures and their health effects. 3rd ed. Hoboken: John Wiley \& Sons, Inc; 2009.

15. Daher N, Hasheminassab S, Shafer MM, Schauer JJ, Sioutas C. Seasonal and spatial variability in chemical composition and mass closure of ambient ultrafine particles in the megacity of Los Angeles. Environmental Science: Processes \&amp; Impacts. 2013; 15(1): 283-95.

16. Rowangould GM. A new approach for evaluating regional exposure to particulate matter emissions from motor vehicles. Transportation Research Part D: Transport and Environment. 2015 January 1; 1(34): 307-17.

17. Santoso M, Lestiani D, Markwitz A. Characterization of airborne particulate matter collected at Jakarta roadside of an arterial road. Journal of Radioanalytical and Nuclear Chemistry. 2013; 297(2): 165-9.

18. Hu Z, Zhang L, Li Y. Investigation of tall oil fatty acid as antiwear agent to improve the lubricity of ultra-low sulfur diesels. Tribology International. 2017 October 1; 1(114): 57-64.

19. Cross E, Sappok A, Fortner E, Hunter J, Jayne J, Brooks W, et al. Realtime measurements of engine-out trace elements: application of a novel soot particle aerosol mass spectrometer for emissions characterization. Journal of Engineering for Gas Turbines and Power. 2012; 134(7): 072801.

20. Lin Y-C, Tsai C-J, Wu Y-C, Zhang R, Chi K-H, Huang Y-T, et al. Characteristics of trace metals in traffic-derived particles in Hsuehshan Tunnel, Taiwan: size distribution, potential source, and fingerprinting metal ratio. Atmospheric Chemistry and Physics. 2015; 15(8): 4117-30.

21. Boogaard H, Kos GP, Weijers EP, Janssen NA, Fischer PH, van der Zee $\mathrm{SC}$, et al. Contrast in air pollution components between major streets and background locations: particulate matter mass, black carbon, elemental composition, nitrogen oxide and ultrafine particle number. Atmospheric Environment. 2011; 45(3): 650-8.

22. Strak M, Steenhof M, Godri KJ, Gosens I, Mudway IS, Cassee FR, et al. Variation in characteristics of ambient particulate matter at eight locations in the Netherlands-The RAPTES project. Atmospheric Environment. 2011; 45(26): 4442-53.

23. Çuvalcı H, Celik HS. Investigation of the abrasive wear behaviour of ZA-27 alloy and CuSn10 bronze. Journal of materials science. 2011 July 1; 46(14): 4850-7.

24. World Health Organization. Air Quality Guidelines 2001.

25. Zhang J, Spikes H. On the mechanism of ZDDP antiwear film formation. Tribology Letters. 2016 August 1; 63(2): 24.

26. U.S. Environmental Protection Agency. Report to congress on black carbon; 2012. 